This is an electronic reprint of the original article. This reprint may differ from the original in pagination and typographic detail.

Author(s): Kajander, Konsta

Title: Terävyyttä etnologiseen tutkimusprosessiin

Year: $\quad 2016$

Version:

Please cite the original version:

Kajander, K. (2016). Terävyyttä etnologiseen tutkimusprosessiin. Elore, 23(2). https://doi.org/10.30666/elore.79268

All material supplied via JYX is protected by copyright and other intellectual property rights, and duplication or sale of all or part of any of the repository collections is not permitted, except that material may be duplicated by you for your research use or educational purposes in electronic or print form. You must obtain permission for any other use. Electronic or print copies may not be offered, whether for sale or otherwise to anyone who is not an authorised user. 


\section{Terävyyttä etnologiseen tutkimusprosessiin}

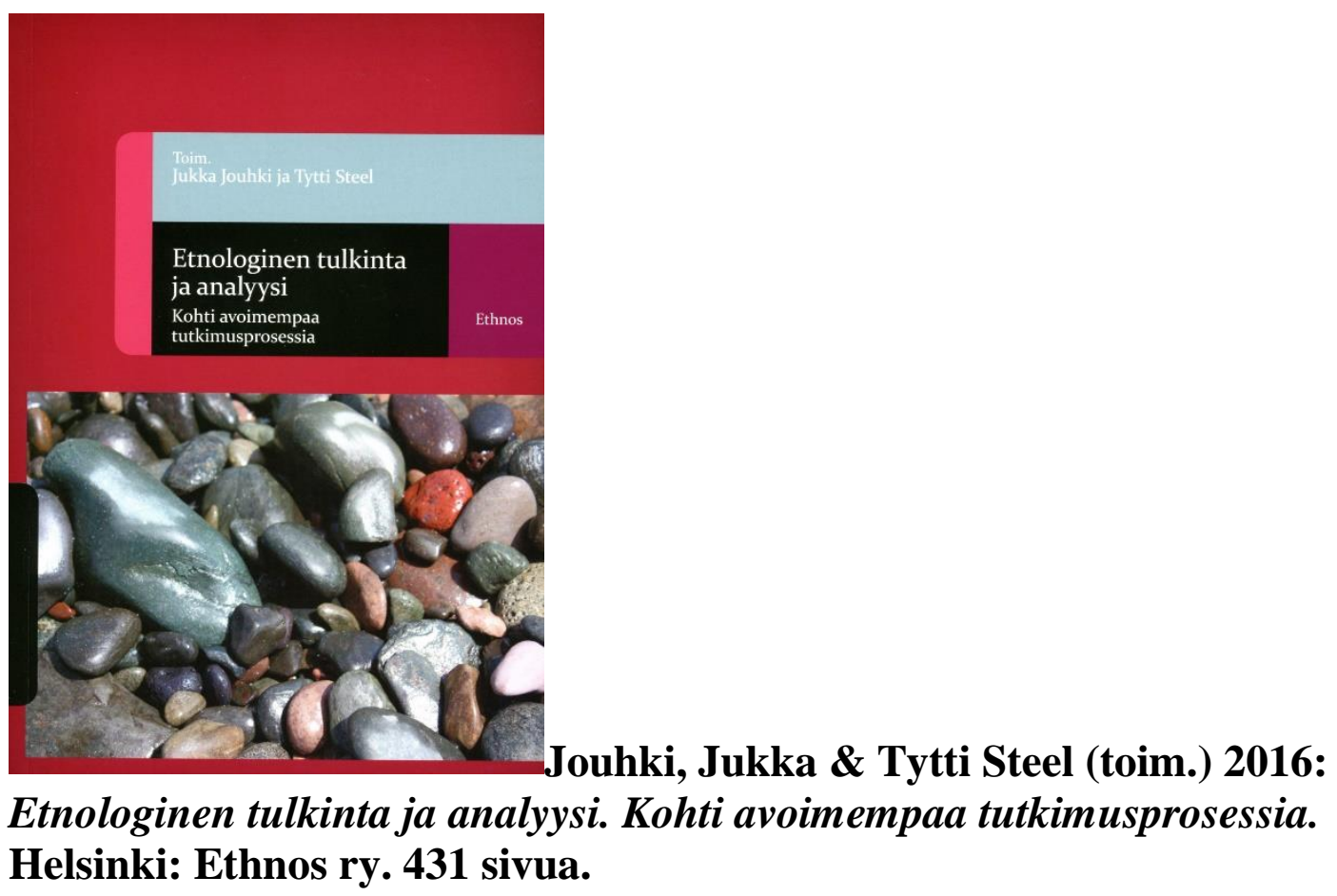

Konsta Kajander

Suomen kansatieteilijöiden yhdistys Ethnos ry on tarjonnut julkaisuillaan keskeisen kotimaisen foorumin etnologian tutkimuskenttien esittelylle. Uuden Ethnos-toimitteen avaamista odottaakin mielenkiinnolla: etnologisen menetelmäkirjallisuuden löytäminen kun voi olla toisinaan kovan työn takana. Sarjassa viime vuosina ilmestyneet artikkelikokoelmat ovat käsitelleet etnografiaa (Hämeenaho \& Koskinen-Koivisto 2014), kulttuuriperintöä (Steel, Turunen, Lillbroända-Annala \& Santikko 2014) ja materiaalista kulttuuria (Nieminen, Olsson, Ruotsala \& Siivonen 2011). Vaikka teoksissa on sivuttu myös teoreettismetodologisia seikkoja, viimeisimmälle etnologisiin menetelmiin keskittyvälle kokoelmalle Polkuja etnologian menetelmiin (Korkiakangas, Olsson \& Ruotsala 2005) on odoteltu jatkoa jo jonkin aikaa.

Kahdeksastoista Ethnos-toimite, Jukka Jouhkin ja Tytti Steelin toimittama Etnologinen analyysi ja tulkinta (2016) ei ole Polkuja etnologian menetelmiin -teoksen seuraaja eikä puhdas menetelmäkokoelma. Sen sijaan teoksessa pyritään kuvaamaan ja selventämään etnologisen tutkimusprosessin kulkua, jonka reflektoiminen kuuluu nykyään tärkeänä osana tutkijoiden menetelmälliseen työkalupakkiin. Teoksen kaksitoista artikkelia perustuvat pääosin Helsingissä vuonna 2014 järjestettyjen VIII Kansatieteen päivien esitelmiin, jotka on jaoteltu kolmeen teemakokonaisuuteen. Ensimmäisessä osassa avataan analyysien ja tulkintojen kuvauksiin liittyviä ongelmakohtia, esitellään vaihtoehtoja etnografiselle esitystavalle sekä kannustetaan tutkittavien osallistamista yhteistyöstävän antropologian kautta. Toisessa osassa kirjoittajat pohtivat tutkimusprosessin dialogisuuteen ja eettisyyteen 
liittyviä kysymyksiä ja kolmannessa esitellään analyysin työvälineitä sekä niiden soveltamista tutkimukseen. Kansatiedettä, etnologiaa, antropologiaa, perinteentutkimusta, folkloristiikkaa, etnomusikologiaa ja kulttuuriperinnön tutkimusta edustavat kirjoittajat tukevat tutkimusprosessiensa kuvauksia tutkimusesimerkeillä, joiden kautta lukija viedään matkoille muisteltuun menneisyyteen, museoihin, puutarhoihin, Lontoon jazzklubeille ja katusoittajien pariin, 1960-luvun Puu-Käpylään sekä internetin parisuhdepalstoille.

\section{Kielen ehdoista yhteiskunnalliseen vaikuttavuuteen}

Tartuin kirjaan aluksi teoreettisella mielenkiinnolla, uusia avauksia etsien. Kuten kirjan toimittajat avausartikkelissaan huomauttavat, kielellinen käänne on muuttanut nykyetnologiaa. Sen seurauksena etnologit eivät niinkään tutki "kulttuuria itsessään, vaan pikemminkin ihmisten käsityksiä kulttuuristaan" (s. 33). Tästä seuraa, että etnologinen tieto on itse asiassa "faktatietoa diskursseista, narratiiveista ja näkemyksistä" (s. 35). Artikkeleiden teoreettis-metodologiset ratkaisut tukevat pitkälti tätä näkemystä eivätkä tarjoa suuria yllätyksiä. Analyyseissä tukeudutaan tuttuun ja turvalliseen hermeneutiikkaan, sosiaaliseen konstruktionismiin, diskurssianalyysiin, laadulliseen sisällönerittelyyn, lähilukuun ja narratiivien tutkimiseen.

Todellisuuden kielellisyyteen ja tutkittavien kokemuksiin perustuva tietokäsitys herättää kysymyksiä kulttuurikäsitteen relevanssista nykyetnologiassa. Pitäisikö etnologien oikeastaan käyttää "kulttuuria" lainausmerkeissä tai peräti luopua käsitteestä kokonaan? Eikö etnologiassa voitaisi tuottaa tietoa ensisijaisesti kulttuurista eikä sitä koskevista käsityksistä? Vastaus riippuu siitä, minkälaiseen tietoon tutkimuksessa tähdätään ja miten tutkijat suhtautuvat kulttuuristen toimijoiden näkökulmiin todistusaineistona. Halutaanko rajoittua tutkittavien ymmärtämiseen, haastatteluihin tai teksteihin, jolloin "kulttuuri" jähmettyy lähinnä teksteihin ja puheisiin jääväksi kielelliseksi konstruktioksi (jonka ulkopuolella ei ole mitään) ja tutkittavien omat käsitykset ovat jo miltei itsessään tutkimustuloksia? Vai toimivatko tutkittavien käsitykset, haastattelut tai tekstiaineistot pikemminkin todisteena jonkin tutkimuskohteena olevan kulttuurisen ilmiön puolesta, jota kulttuurintutkija pyrkii selittämään? Selittäminen ja ymmärtäminen eivät toisaalta ole toisensa poissulkevia vaihtoehtoja, eikä valintaa tarvitse tehdä tutkittavien näkökulmien hylkäämisen tai niihin rajoittumisen välillä. Esimerkiksi tietoteoreettinen realismi mahdollistaisi kulttuurin tarkastelun sekä rakenteena, jolla on valtaa yksilöihin nähden, että prosessina, jonka kautta yksilöt ylläpitävät ja muokkaavat sitä. (Raatikainen 2004, 116-127; Davies 2008, 18-27.)

Huomautettakoon, ettei artikkelikokoelma suinkaan rajoitu hermeneuttiseen tiedonintressiin. Kirjoittajista VIII Kansatieteen päivien key note -luennon pitänyt, tieteen ja teknologian antropologiaan erikoistunut apulaisprofessori Jörg Niewöhner tarjoaa kiinnostavan poikkeuksen kielelliselle näkemykselle. Hän haastaa tutkijoita menemään kielen taakse pohtimaan myös muita maailmassa olemisen tapoja ja kannustaa keräämään ja analysoimaan kyselyiden, tilastollisten mallien ja jopa kaukoantureiden ja satelliittien kautta saatavaa tietoa. Niewöhnerin ohella myös Anna Rastaan ja Aura Kivilaakson artikkelit puhuvat yhteiskunnallisen vaikuttamisen puolesta ja viittaavat samalla kriittis-emansipatoriseen suuntaan. Anna Rastas tarkastelee tapaustutkimuksen kautta museonäyttelyn rakentumista afrikkalaisten diasporasta Suomessa. Hän muistuttaa tutkijoita epistemologisten ratkaisujen vaikutuksesta: valinnat siitä, kenen - ammattilaisen vai tutkittavan yhteisön - näkökulmasta asioita ensisijaisesti tarkastellaan, ohjaavat samalla tutkimuksen lopputuloksia. Toisin sanoen on hyvä pohtia, kenen tiedosta on kysymys. Aura Kivilaakso puolestaan tutkii artikkelissaan kiinnostavasti 1960-luvun sanomalehdissä käytyä Puu-Käpylän kaavoitukseen liittyvää 
aikalaiskeskustelua kriittisen kulttuuriperinnön viitekehyksessä. Vaikka Kivilaakso näkee monitieteisyyden rikkautena, hän myös muistuttaa kansatieteilijöitä pohtimaan, mitä he itse voivat tuoda tieteenalansa edustajina monitieteelliseen keskusteluun.

\section{Retorisesta vakuuttelusta selvempiin perusteluihin}

Kirjan keskeiseksi tavoitteeksi on määritelty "metodologisen magian" eli tutkimusaineistojen keruun ja tulosten väliin jäävän harmaan alueen purkaminen. Käytännössä tämä merkitsee kehotusta aineistojen analyyseihin ja tulkintoihin johtavien prosessien läpinäkyvämpään aukikirjoittamiseen. Kirja onnistuu tavoitteessaan hyvin. Jukka Jouhki ja Tytti Steel eivät kriittisessä avausartikkelissaan tyydy alleviivaamaan ongelmakohtia vaan antavat samalla oivaltavia neuvoja kuvausten parantamiseen. He kannustavat tutkijoita avaamaan paitsi tutkimuksen kirjoitusprosessia myös tutkimuksen aikaisen ajatteluprosessin kehittymistä sekä välttämään itsetarkoituksellisen abstraktin kielen käyttämistä. Esimerkiksi "etnografian", "diskurssin" tai "narratiivin" sijaan voitaisiin puhua selvemmin haastatteluista ja havainnoinnista sekä asioista puhumisen ja tarinallistamisen analysoinnista (vrt. Ingold 2014).

Hyvän esimerkin hienolta kuulostavan menetelmän tarkemmasta määrittelystä antaa Pirjo Uimonen artikkelissaan suomalais-venäläisistä parisuhteista internetin keskustelupalstoilla. Analyysissä käytettävä 'laadullinen sisällönerittely" menettää tosin hieman glamouriaan, kun tekijä selventää menetelmäänsä alaviitteessä ja kertoo tutkivansa teksteistä ihmisten käsityksiä ja tapoja puhua. Uimonen kiteyttää lähestymistapansa vieläkin selvemmin ja täsmällisemmin artikkelinsa lopussa: "käytännössä analysoija poimii tai alleviivaa [..] relevantteja kohtia, koodaa niitä tai tekee kortistoa ja tiivistelmiä” (s. 426).

Ajattelu- ja kirjoitusprosessin lisäksi tutkimuksissa olisi hyvä selventää myös kysymysten kehittymistä. Tutkimushan voidaan periaatteessa kirjoittaa vakuuttavaksi loogiseksi ja koherentiksi kokonaisuudeksi, jossa tutkimusprosessi on edennyt mutkattomasti suunnitelmien mukaan ja analyysi ja johtopäätökset vastaavat ilman muuta alussa esitettyihin tutkimuskysymyksiin ja hypoteeseihin. Museoviraston kansatieteellisen toimiston vuosina 1978-79 teettämää Esinekeruusta entisaikaan -kyselyaineistoa tutkinut Inkeri Hakamies myöntää ilahduttavan avoimesti, ettei aineisto itse asiassa antanut juurikaan vastauksia hänen alkuperäisiin kysymyksiinsä. Tähän vaikutti osaltaan se, että kyselyyn vastaajat ovat joko olleet haluttomia vastaamaan tai eivät ole osanneet vastata kyselyaineiston alkuperäisten laatijoiden kysymyksiin, jotka olivat myös kirjoittajan lähtökohtana aineiston läpikäynnin alkuvaiheessa. Tärkeä on myös Hakamiehen huomautus dialogisen metodologian rajoitteista: tutkijan ja aineiston suhde ei ole analyysivaiheessa tasa-arvoinen, eikä pelkkä aineiston "kuunteleminen" vielä riitä tekemään tutkimuksesta demokraattisempaa (s. 206). Tähän voi lisätä, että dialogista huolimatta valta näkökulmien ja tulkintojen valikoimisesta lopputuotokseen on joka tapauksessa tutkijalla - etenkin jos tutkittavat eivät voi itse osallistua ja vaikuttaa kirjoitusprosessiin.

Yhdessä asiassa "metodologisen magian" purkaminen olisi vaatinut vielä työstettävää. Vaikka nykyetnologia määrittyy pitkälti laadulliseksi tutkimukseksi, se ei merkitse sitä, ettei lukujakin voisi käyttää. Ongelmana kuitenkin on, että lukuja saatetaan käyttää kovin epämääräisesti aineiston valintaa perustellessa (ks. Töttö 2012, 53-79). Tämä näkyy myös artikkelikokoelmassa. Puutarhurina itsekin toimiva perinteentutkija Marjukka Piirainen kertoo poimineensa aineistoonsa noin viidenkymmenen puutarhakirjan lisäksi "runsaasti tekstejä", jotka ovat puutarhurin näkökulmasta kiinnostavia (s. 181), ja Aura Kivilaakso 
ilmoittaa päätyneensä tutkimuskysymysten kannalta "riittävään otantaan" lehtikirjoituksia valitessa (s. 364). Tarkempia perusteluita olisin kaivannut myös Anna Rastaan ilmoittamiin lukuihin: afrikkalaisten diaspora Suomessa koostuu hänen mukaan "kymmenistä tuhansista" ihmisistä ja "kymmenistä" erilaisista yhteisöistä (s. 132).

Pirjo Uimonen määrittelee aineistonsa, Suomi 24-keskustelufoorumin "Monikulttuuriset suhteet" -osion koon tarkasti: 22 viestiketjua ja 526 kommenttia viiden vuoden ajanjaksolta 2004-2009 (s. 397). Aineiston perustelut olisivat vielä vakuuttavampia, mikäli tekijä olisi ilmoittanut, montako 526 kommentista otettiin analyysin kohteeksi ja miksi. Jouhki ja Steel puolestaan ilmoittavat käyneensä läpi "kaikki” Ethnologia Europaeassa vuosina 2010-2014 ilmestyneet 59 artikkelia, 5 johdantoa ja 8 lyhyttä kommenttipuheenvuoroa, joista he ovat etsineet analyysiä ja tulkintaa koskevat sanat (s. 13). En epäile, etteikö näin olisi toimittu, mutta lukija joutuu tekemään töitä lähdeluettelon avulla todetakseen, että ilmoitetun aineiston 72 kirjoituksesta artikkelissa viitataan 31 kirjoitukseen. Ilmeisesti ne olivat myös tekstit, joissa analyysi ja tulkinta esiintyivät?

Aineiston suuri koko ja "koko aineiston" läpikäyminen saattaa näyttää lukijasta vakuuttavalta ja alleviivata tutkijan ahkeruutta ja perehtyneisyyttä työhönsä. Käytännössä lukija saa kuitenkin valmiissa tutkimuksessa nähtäväksi aineistosta vain ne sitaatit, jotka tutkija on siihen valinnut - paitsi jos mukana on erillinen aineistoliite. Tutkijat voisivatkin parantaa avoimuutta reflektoimalla ja aukikirjoittamalla selvemmin ne perusteet, joilla he ovat valinneet juuri tietyt tekstit, arkistolähteet tai haastattelukatkelmat argumentointinsa tueksi. Ja toisaalta, mikäpä estäisi etnologeja ja muita kulttuurintutkijoita kuvaamasta aineistoaan myös yksinkertaisella taulukolla, kuten Eija Stark on aiemmin tässä lehdessä ehdottanut (Stark 2015).

\section{Lopuksi}

Pienistä puutteista huolimatta kirjoittajat ovat onnistuneet selventämään hyvin omia tutkimusprosessejaan, kuvaamaan niin tekstien kuin haastateltavien kanssa käydyissä dialogeissa syntyneitä konflikteja ja onnistumisia sekä perustelemaan työkalujensa valintoja. Pidän lisäksi ilahduttavana, että kokeneempien konkarien ohella tohtorikoulutettavat ovat saaneet tutkimuksilleen sijaa kokoelmassa - ja ovat myös onnistuneet artikkeleissaan hyvin.

Olisin toisaalta kaivannut yhtä "teoriatarinaa" analyysien työkalujen yhteyteen. Teorioita toki esitellään, mutta aihetta olisi voinut syventää tutkimusesimerkillä teoreettisen ajattelun kehittymisestä tutkimusprosessin aikana. Tutkimusprosessin avoimuuden kannalta kiinnostavia kysymyksiä ovat teorioiden, käsitteiden ja aineistojen vuoropuheluun liittyvä haasteet analyysi- ja tulkintavaiheessa sekä tutkimusten alussa valittujen teoreettisten työkalujen muuttuminen tutkimusprosessin seurauksena. Toisaalta etnologian teorioita esittelevälle itsenäiselle kokoelmalle olisi tilausta. Kenties Teoriaa, aihepiirejä ja näkökulmia kansatieteellisessä tutkimuksessa (Pennanen, Sammallahti \& Haapalainen-Tiainen 1985) voisi saada tulevaisuudessa jatko-osan?

Etnologinen tulkinta ja analyysi tulee varmasti löytämään paikkansa paitsi kulttuurin- ja perinteentutkimuksen alojen kurssikirjallisuudesta osana menetelmien opetusta, myös toivon mukaan mahdollisimman monen opiskelijan kirjahyllystä. Varttuneemmille tutkijoille kokoelman artikkelit eivät välttämättä tarjoa suuria mullistuksia, mutta kirjan lukeminen kannattaa, sillä kirjoittajien esimerkit auttavat tarkentamaan katsetta tutkimusprosessien 
kuvausten huomaamattomiin aukkoihin. Jos vielä neuvoista otetaan vaari, kirja on täyttänyt tehtävänsä erinomaisesti.

\section{Kirjallisuus}

Davies, Charlotte Aull 2008: Reflexive ethnography. A guide to researching selves and others. Second edition. London and New York: Routledge.

Hämeenaho, Pilvi \& Koskinen-Koivisto, Eerika (toim.) 2014: Moniulotteinen etnografia. Helsinki: Ethnos ry.

Ingold, Tim 2014: That's enough about ethnography. - Hau: Journal of Ethnographic Theory 4(1): 383-395 [online]. < http://dx.doi.org/10.14318/hau4.1.021 > [7.10.2016.]

Korkiakangas, Pirjo, Olsson, Pia \& Ruotsala, Helena (toim.) 2005: Polkuja etnologian menetelmiin. Helsinki: Ethnos ry.

Nieminen, Aila, Olsson, Pia, Ruotsala, Helena \& Siivonen, Katriina (toim.) 2011: Aineen taikaa. Näkyvän ja näkymättömän kulttuurin jäljillä. Helsinki: SKS.

Pennanen, Jukka, Sammallahti, Leena \& Haapalainen-Tiainen, Helena (toim.) 1985: Teoriaa, aihepiirejä ja näkökulmia kansatieteellisessä tutkimuksessa. Helsinki: Ethnos ry.

Raatikainen, Panu 2004: Ihmistieteet ja filosofia. Helsinki: Gaudeamus.

Stark, Eija 2015: Työn kulttuurista palkkatyön yhteiskuntaan. Kirja-arvio. - Elore 22(1) [online]. < http://www.elore.fi/tyon-kulttuurista-palkkatyon-yhteiskuntaan/ > [7.10.2016.]

Steel, Tytti, Turunen, Arja, Lillbroända-Annala, Sanna \& Santikko, Maija (toim.) 2014: Muuttuva kulttuuriperintö - Det föränderliga kulturarvet. Helsinki: Ethnos ry.

Töttö, Pertti 2012: Paljonko on paljon? Luvuilla argumentoinnista empiirisessä tutkimuksessa. Tampere: Vastapaino.

Filosofian maisteri Konsta Kajander on etnologian tohtorikoulutettava Jyväskylän yliopistossa. 